\title{
Reassessing the Relationship between the Financial Sector and Economic Growth: Dynamic Panel Evidence
}

\begin{abstract}
Historically, the development of the financial sector has been an indispensable driver of economic growth. In the aftermath of the Great Recession there is a pressing need to re-assess the role of the financial sector in the determination of economic growth. Using a dynamic panel framework, our analysis covers 34 European and Commonwealth of Independent States (CIS) economies for the period 1998-2014, and controls for the role of macroeconomic and institutional variables. Our evidence suggests that the potential benefits of the financial sector finance may have dramatically reversed in recent years, resulting in "un-creative destruction". The results suggest, tentatively, that there has been a severance of the link between the financial sector and the real economy. The results, however, vary according to the level of economic development across the European and CIS economies. In the case of developing market economies, the financial intermediation proxies are not significant in explaining economic growth. The effect of changes in investment expenditure, the money supply, wages, unit labour costs and trade openness is found to be strong and in line with a priori expectations across all country samples. Notably, government consumption is also found to be a significant driver of economic growth, except in the developing market economies in the period following the Great Recession. In line with the growing consensus in other research areas, we provide evidence of a robust role for the institutional framework proxied by the quality of governance in determining economic development.
\end{abstract}

Keywords: Economic growth, Financial sector, European economies, CIS.

JEL Classification: E44, F43, P26 


\section{Introduction}

The efficiency of the financial sector in a country is a major determinant of macroeconomic performance. This has been clearly manifested in the aftermath of the Global Financial Crisis (GFC) of 2007-08 and the subsequent Great Recession suffered by many developed and developing economies. At the same time, sustained economic growth remains the single most important determinant of societal living standards (Haldane, 2015). Although the empirical research on the finance-growth nexus has grown in the aftermath of this period, the evidence relating to the European and CIS economies has been relatively scarce and with mixed results. The GFC had severe implications for the financial markets and the economic growth of these regions, substantiating the argument that the relationship between finance and growth is complex and not necessarily stable over time (Grochowska et al., 2014). Thus, the classic question re-emerges as sclerotic growth remains the overriding economic issue of our time (Cochrane, 2015), especially for a number of the countries examined in this paper. Although the financial sector is crucial for the functioning of the real economy, the exact contribution to growth remains uncertain and varies over the business cycle. In this paper, we explore the possibility that the role of the financial sector in terms of its impact on the economy may have fundamentally changed in recent years, controlling for the effect of changes in investment expenditure, wages, unit labour costs, domestic credit, the money supply, the interest rate margin, government consumption, inflation and trade openness.

To explore the role that the financial sector plays in economic growth, one needs to take into account 'frictions' in order to develop a deeper and clearer understanding of the mechanisms in operation (Aghion and Howitt, 2009). Mumtaz et al. (2015) provide evidence that the credit supply shock in the aftermath of the GFC made a large and significant contribution to the decline in GDP growth and inflation in the years that followed, suggesting that frictions associated with financial intermediation play a key role in propagating shocks that drive macroeconomic fluctuations. To explore how the relationship between the financial sector and economic growth may have changed overt ime across Europe and the CIS prior to and following the GFC, we group countries into three sub-samples: advanced, developing markets and the eurozone.

Our results suggest that all of the control variables (investment expenditure, wages, unit labour costs, domestic credit, the money supply, the interest rate margin, government consumption, inflation and trade openness) exert a significant role in determining economic growth. Also, our results indicate significant variation in this role across the three sub-sample groups, suggesting that the finance-growth nexus depends materially on the level of economic 
development. Specifically, in the case of the developing market economies, the proxies for financial sector intermediation (domestic credit and interest rate margin) are found to be insignificant in explaining economic growth over the period under investigation (1998-2014). Furthermore, we find significant variation between advanced and the eurozone economies with respect to the effect of changes in unit labour costs, government consumption and inflation. Irrespective of the classification of countries, our results indicate that institutional quality is a significant driver of economic growth. Thus, good governance does play a critical role in determining the ability of economic agents to operate in a growth-friendly manner.

The rest of the paper is structured as follows: Section 2 reviews the research literature on the finance-growth nexus. Section 3 presents the data and methodology employed in this study whilst Section 4 sets out as well as discusses the empirical results. Finally, Section 5 provides some concluding remarks.

\section{Literature Review}

The intermediating role of the financial sector is so ingrained in the functioning of economies that one may wonder about the need to investigate its importance for the economy (Cetorelli, 2009). Nonetheless, the debate on the determinants of the process of economic growth and the role of the financial sector has been active for over a century. The central question in this debate is whether or not the performance of the financial sector is a fundamental driver of economic growth or merely the consequence of growth (Aghion and Howitt, 2009). If finance interacts with growth, then it is worth exploring the mechanisms underlying this relationship and the implications for macroeconomic policy - particularly as the existing state of knowledge in this field is frequently ignored or "inconvenient realities" are played down (Baily and Elliot, 2013, p.5). Although economists attach different degrees of importance to financial development, its role in contributing to long-term economic growth can be theoretically postulated; this has been supported by the findings of growth empirical studies (Ang, 2008).

On the theoretical front, two pioneering economists that have examined the importance of the relationship between finance and growth were Bagehot (1873) and Schumpeter (1911). Bagehot (1873) emphasized the critical role of the banking system in economic growth and highlighted the conditions under which banks could spur on innovation and growth by funding productive investments. In Schumpeter (1911), the argument put forward was that financial services are paramount in promoting economic growth. Later, Robinson (1952) argued that financial development follows growth, and articulated the causality argument by 
suggesting that "where enterprise leads, finance follows". Although growth may be constrained by credit creation in less developed financial systems, in more sophisticated systems ${ }^{1}$ finance is viewed as an endogenous response to demand requirements. In a reconciling manner, Patrick (1966) uses the supply-leading and the demand-following ${ }^{2}$ set of hypotheses to describe the finance-growth relationship suggesting that both hypotheses can be applied in a sequential manner in the real-world context. In the early stages of economic development, finance stimulates growth by encouraging innovative investments. Once the real economy strengthens, the causality linkage weakens or even reverses since "the supplyleading impetus gradually becomes less important, and the demand-following financial response becomes dominant" (Patrick, 1966, p.177). In contrast, Lin (1981) suggests that the direction of causality between finance and growth "will probably never be settled on either theoretical or empirical grounds" (p.44). Although not conclusive, Lin (1981) finds that financial deepening leads to a higher rate of capital accumulation and a higher level of per capita income.

The balance of research evidence suggests that finance matters for growth. Levine (2005) emphasizes that the theoretical approaches to the relationship between the financial system and growth are premised on the role of the financial sector in reducing information and transaction costs. In line with the Schumpeterian consideration, Rajan and Zingales (2003) stress the ability of finance to spur innovation. However, some economists disagree on the role of the financial sector in economic growth (Levine, 2005). Some suggest that financial intermediaries and markets drive the relationship while their role has been readily dismissed by others (Robinson, 1952; Lucas, 1988). Yet there are authors (Arestis and Sawyer, 2005; Haldane et al., 2010) who remain sceptical not only about the direction of causality, but also on several other issues that need to be factored into the analysis, such as the country-specific dimensions. Although there is ample cross-country evidence suggesting a positive effect of financial development on growth, there are significant discrepancies not only among developing and developed countries (Ahmed, 1998), but also within developing countries due to structural or institutional issues.

A number of other studies confirm the belief that the financial sector does indeed act as an engine of growth for real economic activity (King and Levine, 1993; Levine and Zervos, 1998). Several other authors (Rajan and Zingales, 1986; Demirgüc-Kunt and Maksimovic,

\footnotetext{
${ }^{1}$ This line of argument suggests that the more developed a financial system is, the higher the likelihood of growth-causing finance.

${ }^{2}$ While the supply-leading hypothesis suggests that the financial sector drives growth, the demandfollowing hypothesis attests that when the real sector expands, the demand for financial services increases, thus boosting financial development.
} 
1998; Levine et al., 2000) indicate that the degree of financial sector development plays an important role in stimulating economic growth. Broadly, the message of these studies is that the overall scale and development of the financial sector in general is of significant importance for a country's economic success.

Overall, it would appear that the economics profession has not reached a consensus regarding the direction of causality between finance and growth. Furthermore, the empirical results vary considerably due to the different institutional and structural characteristics of each economy, or the estimation methodology applied (Oguzoglu and Stengos, 2011; Cline 2015). Hence, despite the robustness of such results, sceptics in the underlying debate have always maintained that while the empirical evidence clearly indicates a significant correlation between finance and real activity, it cannot fully address the fundamental issue at stake, namely whether banking activity is exogenously determined and if it is, whether it exerts an independent impulse on real economic sectors (Arestis and Demetriades, 1997). In light of this, the findings obtained from cross-country studies are at best ambiguous and fragile ${ }^{3}$. Arestis et al. (2001) support the view that finance stimulates growth but raises concerns about the strength of the relationship. Examining the relative importance of banks and stock markets in contributing to economic growth in the time series context, Arestis et al. (2001) find that banks are more powerful in promoting economic growth than stock markets. Demetriades and Andrianova (2003) argue that an increase in financial deepening, as captured by standard indicators of financial development, may not result in increased growth because of corruption in the banking system or political interference, which may divert credit to unproductive activities.

More recently, Fink et al. (2009) find that domestic rather than private credit is a significant factor in promoting growth for nine EU accession countries during 1996-2000. The study by Hagmayr and Haiss (2007) on the finance-growth nexus in four South-East European countries covering the period 1995-2005 concludes that financial intermediation, measured by private credit, has had a negative effect on growth in the short-run that becomes positive, albeit insignificant, when lags are used. On the same wavelength, Yildirim et al.'s (2013) study concludes that the direction of causality in the growth-finance nexus exhibits considerable differences across developing European economies and depends largely on the chosen indicators. Therefore, the effect of country-specific features needs to be incorporated

\footnotetext{
${ }^{3}$ The results are subject to the sample of developed and developing countries included in the estimation, the control variables used, the time period covered and the econometric techniques employed (Arestis and Demetriades, 1997).
} 
into the empirical research (Arestis and Demetriades, 1997; Rousseau and Wachtel, 2005). In addition, this study by Caporale et al. (2009) on ten previously centrally-planned economies of Central and Eastern Europe found no causal linkages between credit to the private sector and economic growth. The authors attribute their finding to the lack of financial depth in the sample countries that in turn limits the contribution of under-developed banking systems to growth.

Broadly, in cross-country studies, financial deepening has been found to yield a positive effect on medium-term growth (Beck and Levine, 2004). This would suggest that the rise in the scale and scope of banking sector activities over recent decades has provided a significant tailwind to medium-term growth, especially in advanced countries - or so it seemed in the pre-crisis period, as Haldane (2012) argues. Recent research suggests that financial deepening can indeed be growth-positive but within certain limits. As Arcand et al. (2012) argue, there is a certain threshold at which the ratio of private credit-to-GDP may begin to have a negative impact on GDP growth ${ }^{4}$. This finding is consistent with earlier cross-country evidence suggesting that, at credit-to-GDP ratios above unity, output volatility tends to increase (Easterly et al., 2000). In a study capturing 150 countries for the period 1975-2005, Barajas et al. (2013) claim that the beneficial effect of financial deepening on economic growth displays heterogeneity across regions and income levels. Rousseau and Wachtel (2002) find that the effect of financial development on economic growth is significantly positive only when inflation is below 5-6 per cent, with the largest effect taking place during periods of disinflation. In a subsequent study, Rousseau and Wachtel (2011) indicate that the relationship between financial deepening and growth may be weaker for developing countries and may have weakened in recent years. In contrast with Rousseau and Wachtel (2005), Dal Colle (2011) identifies a long-run equilibrium relationship between financial and economic development using data up to 2006, covering African, Asian and Latin American developing countries whose history has been characterized by prolonged periods of high inflation and episodes of crisis or other structural change.

It follows from a review of the literature that there is an absence of consensus concerning the extent to which financial deepening is a critical path for the overall development process of a country. It seems that it is not only the GFC that has shed doubt on the finance-growth nexus relationship but there are other fundamental issues that need to be addressed. Aghion et al. (2005) find that the relationship becomes insignificant at higher levels of economic

\footnotetext{
${ }^{4}$ The authors find a non-linear growth impact of banking sector depth that progressively becomes weaker as the depth increases to high levels. Eventually, when private sector credit exceeds $110 \%$ of GDP, the marginal effect of additional deepening on the economy becomes negative.
} 
development, while Arcand, et al. (2012) show that the relationship turns negative at very high levels of financial development. Cecchetti and Kharroubi (2012) examine how financial development affects growth at both country and industry level. They find the level of financial development is a good predictor but only up to a point, after which it becomes a drag on growth. In other words, financial booms are not, in general, growth-enhancing. These results of a U-shaped financial development effect are consistent with the diminishing effect reported by Rousseau and Wachtel (2011). Aizenman et al. (2013) find that periods of accelerated growth of the financial sector are more likely to be followed by abrupt financial contractions than are periods of slower financial sector growth. In a following contribution, Aizenman et al. (2015) provide evidence of large differences between developing Asia and Latin America in terms of the impact of financial depth on sectoral growth. At the same time, they validate the negative impact of financial deepening on output growth in several sectors, suggesting that financial development may promote only limited growth in the real economy - implying that further financial development may have no effect or even a negative effect on growth.

It is clear, therefore that any argument that development of the financial sector unambiguously leads to sustained economic growth needs to be treated with caution (Odhiambo, 2007). Despite longitudinal data and empirical evidence, the ingredients of growth remain suspended between the "mundane and the miraculous" (Haldane, 2015, p.22). For instance, Gimet and Lagoarde-Segot (2012), using VECM and GMM estimations for a panel of 138 countries, show that rather than solely focusing on the size of the banking sector, what matters most for fostering economic growth is the ability of the bankning sector to fulfil its functionality. Similarly, Boukhatem (2016), using a panel of 67 low and middle income countries provides robust evidence that financial development emanating from a stable banking systems alleviates poverty.

In the following sections we make a contribution to this debate by exploring the nexus for a group of 34 countries, most of which have experienced fundamental paradigm shifts in recent years and particularly since the onset of the GFC. These countries span both the European Union and members of the CIS. Their diversity in terms of financial and macroeconomic development has the potential to offer important insights into this critical research topic.

\section{Data and Methodology}

There is considerable divergence across the European economies in terms of economic performance and financial structure. At the same time, while some post-Soviet countries within the CIS have developed their financial systems by enabling the participation of foreign 
banks, others have taken proactive steps to deepen and to strengthen the scale and scope of financial intermediation within their economies. Figure 1 displays the domestic credit provided by the financial sector as a percentage of GDP for four geographical regions namely; the Euro area, Europe and Central Asia (all income levels), Europe and Central Asia (developing only), and Central Europe and the Balkans.

\section{Insert figure 1}

Figure 1 illustrates, on the basis of domestic credit expansion, the extent of diversity across European and CIS countries. Clearly, the level of financial intermediation ${ }^{5}$ in Europe (including Central Asia) remains significantly lower compared to the eurozone. A steep growth in domestic credit (as \% of GDP) is evident in all regions starting around 2003-04 up until the onset of the GFC. The overall credit contraction in the eurozone is partly derived from the persistent depressive effects of the financial turmoil in 2007-2008. In addition, the European sovereign debt crisis, which has been going on since 2010, has resulted in an uncertain economic environment. Broadly, different patterns can be observed at a more granular level, between the eurozone countries and the European developing countries.

\subsection{Empirical Investigation}

For the empirical investigation an econometric model is formulated and estimated for a pool of 34 developed and developing economies spanning the period 1998-2014. To analyse the link between financial development and economic growth a number of other growth determinants are controlled for. We initially provide estimates for the entire pool of countries in the dataset. We then split the dataset into advanced, developing, and eurozone countries and provide additional estimations for these respective clusters. The 34 countries used in the empirical analysis are shown in Appendix, Table A3.

In exploring the relationship between the financial sector and growth, we estimate an augmented Barro (2003) growth model incorporating financial development variables, which is couched in the following form:

$$
g_{i, t}=a_{i}+\beta_{i\{}\left\{\operatorname{FIN}_{i, t}\right\}+\gamma_{i}\left\{M A C R O C T R L_{i, t}\right\}+\delta_{i}\left\{\operatorname{INSTCTRL}_{i, t}\right\}+v_{i}+\varepsilon_{i, t}
$$

\footnotetext{
${ }^{5}$ The metric used is just for comparative purposes as it is well known that different measures of financial development can give rise to different conclusions in empirical studies (Stengos and Liang, 2005; Ang, 2008). Thus, the usual disclaimer applies in Figure 1.
} 
where $g_{i, t}$ is the real growth rate of GDP per capita , $\operatorname{FIN}_{i, t}$ denotes financial development, $M A C R O C T R L_{i, t}$ is a set of macroeconomic controlling variables, INSTCTRL $L_{i, t}$ is a vector of institutional variables, $\mathrm{v}_{\mathrm{i}}$ and $\varepsilon_{i t}$ are the error terms; $i$ denotes a country (where $i=1,2, \ldots, \mathrm{N}$ ) and $t$ the time period (where $\mathrm{t}=1,2, \ldots, \mathrm{T}$ ); $\varepsilon$ is a white noise error with zero mean and $v$ a country-specific component of the error term that does not necessarily have a zero mean; $\alpha_{i}$ is a parameter reflecting a variant country-specific intercept.

\subsection{The Variables}

Within the extant literature on the finance-growth nexus, many research studies have identified a number of various proxies to capture the relationship between growth and financial development. Amongst others, Beck et al. (2000), in attempting to capture the size, activity and efficiency of the financial sector, have proposed different indicators of financial development. In our analysis, we have considered a number of potential indicators to proxy financial development: domestic credit provided by the financial sector as a percentage of GDP; the margin between lending and deposit interest rates, the real lending interest rates, the money supply and quasi money supply (M2) as \% of GDP, the total value of stocks traded as a percentage of GDP and the market capitalisation of listed companies as a percentage of $\mathrm{GDP}^{6}$.

In particular, following Levine and Zervos (1998) we initially utilize the ratio of domestic credit to the private sector as $\%$ of GDP as a proxy for financial sector depth whilst financial sector efficiency is proxied by the interest rate margin. In the growth-finance literature a number of potential economic growth indicators have been proposed such as: real per capita GDP growth; average per capita capital stock growth and productivity growth (Levine, 1997). In this study, real per capita GDP growth has been selected to serve as the dependent variable rather than simply GDP growth to take account of people's prosperity rather than investors' prospects.

In so far as data availability permits, the explanatory variables that are thought to condition economic growth are: investment, wages, unit labour costs, domestic credit, interest rate margin, the money supply, government consumption, inflation and trade openness. It should also be noted that the lagged value of the dependent variable - real GDP per capita - is

\footnotetext{
${ }^{6}$ While we have considered all available proxies for all sub-groups (advanced, developing and eurozone countries), it appears that the ratio of M2/GDP is more appropriate for the developing economies while the stock-exchange related ones (market capitalization, value of traded stocks) are more appropriate for the advanced or eurozone countries. Equally, the real lending rate has been used as an alternative proxy to the spread between lending and deposit rates.
} 
included in all estimated models to control for the steady-state convergence predicted by the neoclassical growth model (see Appendix Table A1 for the definition of variables).

Investment is instrumental in the determination of growth in the majority of economic growth models (Barro, 2003; Mankiw et al., 1992; Sala-i-Martin, 1997). The neoclassical growth model indicates that today's investment drives tomorrow's growth in the spirit of the SolowSwann approach (Solow, 1956; Swann, 1956).

Average wages together with government consumption have been incorporated into the model to capture the Keynesian argument that higher wages as well as higher government spending boost aggregate demand and through this economic growth (Alexiou and Nellis, 2013; Arestis and Saywer, 2005). It is in this sense that a positive sign is expected for average wages during the estimation. Equally, in the case of government consumption, we would expect a higher growth rate of consumption to have a positive effect on national economic growth. From a demand-side perspective, higher government spending may stimulate growth but, if excessive, may lead to higher inflation rather than growth. From a supply-side perspective, government spending has the potential to stimulate economic activity. But, in contrast, some could argue that higher public spending may be linked to other negative phenomena, such as excessively high public sector wages, inefficient state enterprises or, in some countries, to a high level of corruption which may stifle growth.

The unit labour cost variable attempts to capture competitiveness. According to IMF (2003), lower unit labour costs enhance the efficacy of the adjustment of the economy through the channel of price competitiveness. Thus, a negative sign is envisaged to reflect the inverse relationship between cost of production and economic growth.

Trade openness, proxied by the percentage change in the value exports of goods and services, is expected to bear a positive coefficient. In theory, a greater degree of openness is likely to contribute to growth through greater competition and technological progress (Winter, 2004). At the same time, the empirical evidence on the interaction of economic growth, financial development and trade openness provides some contrasting views. For instance, Sakyi et al. (2015) provide evidence of a positive relationship between trade openness and the level of national income in the long run in a sample of 115 economies for the period 1970-2009 while Kim et al. (2012) find that trade promotes economic growth in high-income, low-inflation, and non-agricultural countries but has a negative impact on growth in countries with the opposite attributes. 
Inflation is a measure of the degree of economic uncertainty and is expected to be negatively associated with economic growth in that businesses are likely to be less willing engage in long-run investment in the presence of higher price variability (Barro 2003). Fischer (1993) has also supported the negative relationship between inflation and growth due to decreasing investment, savings and capital accumulation. Also, inflation can be thought of as a proxy for institutional development (Schnabl, 2007).

The growth of the money supply is a monetization variable which serves as a measurement of the growth in the size of the financial sector. Growth in the money supply is expected to yield a positive effect on economic growth (Feldstein and Stock, 1993). At the same time, the inclusion of the money supply allows us to study the dynamics of the interactions between credit conditions, monetary policy and economic growth, particularly in the pre-crisis and post-crisis periods as the European and CIS countries have moved from one phase of the business cycle to another.

The empirical analysis controls for both the quantity and quality of financial intermediation. The former is proxied by the ratio of domestic credit-to-GDP provided by the financial sector. Financial efficiency is measured by the lending-deposit interest rate spread. This not only reflect the costs of financial intermediation but it also reflects banking market competitiveness. We recognize that the measures of financial intermediation used in this study and elsewhere in the related literature may be too crude to capture the reality of modern financial systems. Nonetheless, the literature has not yet developed sufficiently reliable metrics to properly gauge the relationship between financial intermediation and economic growth.

Finally, a set of governance indicators has been incorporated to account for the quality of the institutional framework in the growth-finance equation in line with the growing consensus that governance matters for economic development (for more on this see Kaufmann et al. 2010). The descriptive statistics for the variables that enter our final parsimonious models are presented in Appendix in Table A2.

\subsection{Model Specification}

We adopt a dynamic panel data model approach using the Generalised Method of Moments (GMM) framework originated by Holtz-Eakin et al. (1988) and further advanced by Arellano and Bond (1991) and Arellano and Bover (1995); accordingly we employ the two-step procedure and obtain robust standard errors with Windmeijer's (2005) finite sample 
correction. According to Arellano and Bond (1991) and Arellano and Bover (1995) the particular framework is well suited for datasets with small $T$ and larger $N$. Additional benefits of the GMM approach are that is also well-suited for dealing with the bi-directional causality between variables; the possible endogeneity of explanatory variables, as well as omitted variable biases; time invariant country characteristics (fixed effects) that may be correlated with the explanatory variables; and the presence of autocorrelation (Bond, 2002; Caselli et al., 1996).

The dataset used spans the period 1998 to 2014, consisting of N cross sectional units, denoted $i=1, \ldots, \mathrm{N}$ observed at $\mathrm{T}$ time periods, denoted $t=1, \ldots, \mathrm{T}$. More specifically, $y$ is a $(T N \times 1)$ vector of endogenous variables, $x$ is a $(T N \times k)$ matrix of exogenous variables, which does not include a column of units for the constant term. In this context, we collect data for a cross section of 34 economies $(N=34)$, over a period of 17 years $(T=17)$.

The full list of countries is set out in Appendix Table A3. We initially estimate equations using a general-to-specific approach for the entire dataset and then we split the dataset into three groups, i.e. advanced, emerging/developing and Eurozone countries. In doing so, we estimate various specifications, the explicit form of which is couched in the following terms:

$g d p p c_{i t}=a_{0}+a_{1} g d p p c_{i t-1}+a_{2}$ wage $_{i t}+a_{3} u c_{i t}+a_{4}$ cre $_{i t}+a_{5}$ intm $_{i t}+a_{6} g c o n_{i t}+a_{7}$ inf $_{i t}+$ $a_{8}$ open $_{i t}+a_{9} m s_{i t}+a_{10} i n v_{i t}+a_{11} v a_{i t}+a_{12} p s_{i t}+a_{13} r q_{i t}+a_{14} r l_{i t}+a_{15} g e_{i t}+a_{16} c c_{i t}+u_{i t}(1)$ $u_{i t}=v_{i}+e_{i t}$

By taking the first difference of the regressors, the fixed-country specific effect is completely removed, in so far as it does not vary with time. From equation (2) we get:

$\Delta u_{i t}=\Delta v_{i}+\Delta e_{i t}$

where $g d p p c$ is GDP per capita, $g d p p c_{t-1}$ is lagged GDP per capita, wage is the wage rate, ulc stands for unit labour costs, cre is the credit provided by the financial sector, intm is the interest rate margin, gcon denotes government consumption, inf stands for inflation rate, open denotes trade openness, $m s$ is the growth rate of $\mathrm{M} 2$, and inv denotes investment; the institutional variables consist of $v a$ which denotes voice and accountability, $p s$ is political stability, $r q$ denotes regulatory quality, $g e$ is government effectiveness, $r l$ stands for rule of law and $c c$ measures control of corruption; $u_{t}$ is the disturbance term, $v_{i}$ captures the 
unobserved country specific effect while $e_{i t}$ is the idiosyncratic error. This is a one-way error component regression model, where $v_{i} \sim \operatorname{IIN}\left(0, \sigma^{2}\right)$ and independent of $e_{i t} \sim \operatorname{IIN}\left(0, \sigma^{2}\right)$.

Testing for stationarity in panel data models is a matter of interest and it seems fairly intuitive. In recent years, a number of unit root tests have been developed - such as those by Levin, Lin and Chu, (2002), Im, Pesaran and Shin (2003) among other which are shown to be more powerful than the unit root tests applied to individual series. While these tests are commonly termed 'panel unit root' tests, theoretically speaking they are simply multipleseries unit root tests that have been applied to panel data structures (Alexiou et al., 2016). In this study we utilize both common root tests - Levin, Lin, Chu (LLC) - and individual root tests - Im, Pesaran, Shin and ADF, Fisher. Table 4A in Appendix sets out the results of the respective tests on the basis of which the null hypothesis of a unit root is rejected in all cases. The implication of the latter is that whilst a short run relationship might exist there is no need to explore cointegrating relationships (Boukhatem, 2016).

The results for the baseline model are presented in Table 1 below. It should be stressed that whenever there is considerable difference between the Fixed Effects (FE) and the GMM estimates (mostly in terms of the significance of the coefficients), the Hausman test is effectively applied to determine which model is the most consistent one. In view of the above, the focal point of the analysis that follows will be on the GMM-SYS specification, the generated estimates of which are the most reliable ones. In testing the consistency of the estimators, Arellano and Bond (1991) suggest testing the hypothesis that there is no secondorder serial correlation for the disturbances of the first-differenced equation. In addition, Arellano and Bond (1991) propose performing the Sargan's test of over-identifying restrictions. If the model is over-identified, the latter test is conducted to investigate whether the over-identifying restrictions are close to zero to be consistent with their validity when evaluated at the optimal GMM parameter estimators (Bond, 2013). Another test for overidentifying restrictions is the $J$ statistics of Hansen. The two tests for over-identifying restrictions are linked where the Sargan's statistic is considered a special case of the Hansen's $J$ statistic under the assumption of conditional heteroskedasticity (Baum et al., 2003). Roodman (2006) suggests that if "non-sphericity is suspected in the errors, as in robust onestep GMM, the Sargan test statistic ... is inconsistent. In that case, a theoretically superior over-identification test for the one-step estimator is that based on the Hansen statistic from a two-step estimate" (p. 12).

To test robustness of our GMM-SYS estimates we use the AR(2) and Hansen tests on the basis of which the null hypothesis of no serial correlation and instrument validity can not be 
rejected. More specifically, the results support the validity of the over-identifying restrictions and the absence of second order serial correlation in all regressions, thus providing support to the reliability of the estimates.

\section{Insert Tables 1, 2, 3 and 4}

As a robustness test, but also to account for the potential change in dynamics of the interactions between finance and economic growth in the pre-crisis (1998-2008) and postcrisis (2008-2014) periods, we re-estimate the equations by splitting the time period into two sub-periods. Avdjiev and Zeng (2014) provide evidence that credit market conditions, monetary policy and economic activity in the US changes considerably as the economy moved from one phase of the business cycle to another. We expect a similar phenomenon across the 34 countries in our sample as they are expected to have moved from one phase of the business cycle to another during the Great Recession. The results of these estimations are reported in Appendix Tables A5 and A6.

\section{Empirical evidence}

Overall, the estimation results across all datasets are statistically robust and reliable. It should be noted, however, that the results differ significantly for advanced and developing economies. More specifically, the financial intermediation variables, i.e. the ratio of domestic credit-to-GDP (cre) and the interest rate margin (intm), are found to be insignificant and therefore were dropped from the estimation process in the case of the developing economies dataset while they were found to be highly significant in the rest of the clusters. It is also worth highlighting that the credit variable bears a negative sign in all estimated models whilst the interest rate margin is positively related to economic growth in the entire dataset and negative in the rest of the clusters. The latter is in stark contrast with the general consensus shaped in 1980-2000 that 'plain' finance contributes to economic growth. This result is in line with those obtained by Cojocaru et al. (2015) in a study for 23 CIS and CEE countries for the period 1990-2008 in which they found a statistically significant negative effect of interest rate spread on economic growth. Furthermore, the interest rate margin becomes significant in the sub-samples, 1998-2008 and 2009-2014, although it yields a positive effect on economic growth (see Appendix Tables A4 and A5). Simply put, increased credit flows to the economy should matter for growth as long as particular structural features of the financial sector(s) are in place to promote financial inclusion and entrepreneurship. Notably, the effect of other measures of financial development such as real lending margins, monetary aggregates, market 
capitalisation or the value of stocks traded did not prove to be significant in conditioning economic growth.

In addition, the effect of the intm variable is positive and significant for the entire sample of countries while it becomes negative in the case of advanced and eurozone economies in the baseline model, possibly due to the prolonged period of low interest rates in the aftermath of the global financial crisis. The latter can be also attributed to the fact that interest rates have become less of a weapon in the hands of monetary authorities for spurring growth. At the same time, the persistently lower interest rate margins in advanced and eurozone countries relative to developing ones may signal a higher level of financial development. In the case of developing economies, and contrary to the conventional wisdom from prior studies, the effects of credit, lending-deposit margin, government consumption and inflation on economic growth are not clear cut.

To some extent, our results (especially for the advanced and eurozone economies) confirm to some degree those reported by Cecchetti and Kharroubi (2012) who suggest that beyond a certain point, financial deepening is associated with slower rather than faster economic growth. Arcand et al. (2012) find negative effects of additional financial deepening when credit to the private sector exceeds $100 \%$ of GDP - as is the case with the advanced and eurozone economies - arguing that the usual specification in earlier estimates failed to allow for the possibility of a reversal of the sign. At the same time, a rapid credit expansion as experienced in developing Europe in the pre-crisis period affects growth adversely. An indirect effect of the financial sector relates to the effect of trade openness, as financial institutions are assumed to facilitate trade. In all estimates, irrespective of time period and group of counties, the effect of trade openness remains robust and positive in line with $a$ priori expectations and previous empirical studies.

The results show that inflation has a negative effect on economic growth across the entire dataset and eurozone economies. In the case of the entire dataset this is an expected outcome given the degree of variability in inflation rates across the 34 countries. This is in line with results reported by Bruno and Easterly (1998) who assert that inflation is more likely to negatively affect economic growth in a high inflationary environment. However, in the case of the eurozone economies with relatively stable and convergent inflation rates one might expect a different outcome. In line with expectations, government spending is a strong driver for growth not only in the entire dataset but also in all the sub-groups considered. Furthermore, the results are in line with recent evidence from 25 Asian countries for the period 1980-2012 (Ghazanchyan et al., 2015). Finally, the effects of investment, wages, unit 
labour costs and the money supply remain robust across all sub-groups in the model whilst in the post-crisis period, the effect of unit labour costs is found to be insignificant. Although it is well known that over long periods of time, economic growth comes from productivity as measured by the unit labor costs, it could be the case that in the aftermath of the GFC other forces came into play forestalling the impact of productivity. Government spending is significant and in the anticipated direction in all subgroups for the pre-crisis period. In the post-crisis period, the effect of government spending is insignificant only for the developing economies, possibly owing to lagged contagion effects from the Great Recession along with increasing austerity associated with government spending.

Without an in-depth understanding of the financial environment of each country, the crosscountry evidence yields little policy insights. Analyses conducted at aggregate level may fail to capture or account for the complexity of each country's financial architecture or other specificities related to their development process. Interestingly, in both the advanced and the eurozone economies, the effect of the financial intermediation proxies would seem to be a hindrance to economic growth as they exhibit a negative sign. Consequently, it appears that in the time-period of the study, several forces co-influence growth in developing countries reversing the expected effect of finance. Three tentative remarks may be made on the basis of the results reported above:

a. Financial intermediation matters for growth. The empirical evidence indicates clearly a correlation between developments in the financial sector and real economic activity. Yet, the link between finance and growth has an asymmetric nature possibly owing to the macroeconomic volatility which seems to have an economically strong impact in our sample of countries and across the time period chosen. In this respect, macroeconomic volatility tends to reduce financial depth which in turn adversely affects economic development.

b. The empirical results vary considerably due to the different institutional and structural characteristics of each sub-group. The results for the sub-periods also vary considerably across the same sub-group of countries. This variation may be explained by a number of factors such as differences in regulatory, monetary and macroeconomic policies; political, legal and even historical or geographical factors cannot be overlooked. Equally, the selection of variables to indicate the level of financial development and to measure the extent or efficiency of financial intermediation is critical in empirical studies of this nature, particularly in the context of less developed economies. 
c. Good governance is essential for growth. Regardless of time period or group of countries (advanced, developing or eurozone), the quality of the institutional framework is instrumental in stimulating economic growth. While the effect of other variables does diminish or variates over time, good governance pays off, especially in the case of developing countries thus, raising the need to be placed on top of policy makers initiatives for spurring growth. The research agenda therefore should be shifted towards not just quantity but also to the quality of institutions and finance.

\section{Conclusions}

Historically, the development of the financial sector has been an indispensable component of economic growth. A large body of evidence points to the benefits of financial development, recognizing the value of financial intermediation in mobilizing savings, reducing information asymmetries and acting as a catalyst for investment. The intrinsic power of the financial sector essentially lies in its linkage to the economy - finance exists to serve the real economy. In recent decades, however, finance has progressively shifted from being an enabler of growth to an engine of growth in its own right. In the aftermath of the GFC and the seismic shifts that have taken place across Europe and the CIS, many observers have argued that there has been a fundamental erosion of the finance-real economy linkage. Controversially, it is further argued that the finance sector has progressively deviated from its long-term value creation role and moved in the direction of excessive emphasis on short-term gains. In the years prior to the GFC, domestic credit provided by financial sectors in Europe and the CIS had far outstripped real economic activity in these regions. It is in this context that we have carried out this research and attempted to make a useful empirical contribution to an assessment of the finance-growth nexus.

The evidence presented here suggests that the potential benefits of the financial sector may have been dramatically reversed in recent years resulting in "un-creative destruction". The results are in line with those of several other empirical studies which show that the return to growth from finance diminishes or even becomes negative at a high level of financial development. In other words, too much finance may be "costly" for economic growth. In this respect, the results suggest a potential weakening of the direct link between finance and the real economy. In all estimates reported in this paper, the degradation of finance eventually rendered its function of intermediation as ineffective, causing more harm than good to economic growth. The results for the sub-samples of the advanced, developing markets and eurozone economies across the EU and CIS exhibit significant variation suggesting that the 
finance-growth linkage and the transmission mechanisms differ substantially depending on the level of development. In the case of developing market economies, the financial intermediation proxies are not significant in explaining economic growth.

Lastly, irrespective of the classification of countries, our results suggest that institutional quality plays a key role in determining the ability of economic agents to operate in a growthfriendly manner. By symmetry, developing countries appear to have higher payoffs in terms of real GDP growth when improving institutional quality.

These results have important implications for macroeconomic growth and regulation of the financial sector. It is clear that unconstrained expansion of finance may result in more costs than benefits in the future which translates to quality matters much more than quantity.

\section{References}

Aghion, P. and Howitt, P. (2009) The Economics of Growth. Massachusetts: MIT Press.

Aghion, P., Howitt, P. and Mayer-Foulkes, D. (2005) The Effect of Financial Development on Convergence: Theory and Evidence. Quarterly Journal of Economics, 120:173-222.

Ahmed, S. (1998) Comment on 'The Legal Environment, Banks, and Long-Run Economic Growth'. Journal of Money, Credit, and Banking, 30:614-620.

Aizenman J., Pinto, B., and Sushko, V.I. (2013) Financial Sector Ups and Downs and the Real Sector in the Open Economy: Up by the Stairs, Down by the Parachute. Emerging Markets Review, 16:1-30.

Aizenman J, Jinjarak, Y. and Park, D. (2015) Financial Development and Output Growth in Developing Asia and Latin America: A Comparative Sectoral Analysis. NBER Working Paper, 20917.

Alexiou, C., Tsaliki, P. and Tsoulfidis, L. (2016) Classical Theory of Investment: Panel Cointegration Evidence from Thirteen EU Countries, Contributions to Political Economy, 35(1): $1-18$.

Alexiou C, Nellis J (2013) Challenging the Raison d'etre of Internal Devaluation in the Context of thr Greek Economy. Panoeconomicus, 60(6): 813-836.

Ang, J.B. (2008) A Survey Of Recent Developments in the Literature of Finance and Growth. Journal of Economic Surveys, 22(3): 536-576. 
Arcand, J.L., Berkes, E., and Panizza, U. (2012) Too Much Finance? IMF Working Paper $12 / 161$.

Arellano, M. and Bond, S. (1991) Some Tests of Specification For Panel Data: Monte Carlo Evidence and An Application To Employment Equations. The Review of Economic Studies, 58: $277-297$.

Arellano, M. and Bover, O. (1995) Another Look at The Instrumental Variable Estimation Of Error-Component Models. Journal of Econometrics, 68: 29-51.

Arestis, P. and Demetriades, P.O. (1997) Financial Development and Economic Growth: Assessing the Evidence. Economic Journal, Royal Economic Society, 107(442): 783-799.

Arestis, P., Demetriades, P.O. and Luintel, K.B. (2001) Financial Development and Economic Growth: the Role of Stock Markets. Journal of Money, Credit, and Banking, 33:16-41.

Arestis, P. and Sawyer, M. (2005) Financial Liberalization and the Finance-Growth Nexus: What Have We Learned? In Arestis, P. and Sawyer, M. (eds.) Financial Liberalization Beyond Orthodox Concerns. Hampshire, Palgrave Macmillan.

Avdjiev, S. and Zeng, Z. (2014) Growth, Monetary Policy, and Economic Activity in a ThreeRegime TVAR Model. BIS Working Paper, 449.

Bagehot, W. (1873) Lombard Street: A Description of the Money Market. New York, E. P. Dutton and Company.

Baily, M.N. and Elliott, D.J. (2013) The Role of Finance in the Economy: Implications for Structural Reform of the Financial Sector. The Brookings Institution, Paper, 7.

Barajas, A., Chami, R. and Yousefi, S.R. (2013) The Finance and Growth Nexus Reexamined: Do all Countries Benefit Equally? IMF Working Paper, 130.

Barro, J.R. (2003) Determinants of Economic Growth in a Panel of Countries. Annals of Economics and Finance, Society for AEF, 4(2): 231-274.

Baum, C. F., Schaffer, M. E., \& Stillman, S. (2003). Instrumental variables and GMM: Estimation and testing. Stata Journal, 3(1): 1-31.

Beck, T., Levine, R., Loayza, N. (2000). Finance and the Sources of Growth. Journal of Financial Economics, 58: 261-300.

Beck, T. and Levine, R. (2004) Stock Markets, Banks, and Growth: Panel Evidence. Journal of Banking and Finance, 28: 423-442.

Bond, S. (2013). Dynamic models II - System GMM and related estimators implementation in Stata. Oxford, UK: University of Oxford.

Bond, S. (2002) Dynamic Panel Data Models: A Guide to Micro Data Methods and Practice. The Institute for fiscal studies, Department of Economics, UCL, Cemmap working paper CWP09/02.

Boukhatem, J. (2016) Assessing the direct effect of financial development on poverty reduction in a panel of low- and middle-income countries. Research in International Business and Finance, 37: 214-230. 
Bruno, M. and Easterly, W. (1998) Inflation Crises and Long-run Growth. Journal of Monetary Economics, 41:3-26.

Caporale, G.M., Rault, C., Sova, R. and Sova, A. (2009) Financial Development and Economic Growth: Evidence from Ten New European Union members. International Journal of Finance and Economics, 20: 48-60.

Caselli, F., Esquivel, G. and Lefort, F. (1996) Reopening the Convergence Debate: A New Look at Cross-country Growth Empirics. Journal of Economic Growth, 1(3): 363-389.

Cecchetti, S. and Kharroubi, E. (2012) Reassessing the Impact of Finance on Growth. BIS, Working Paper No 381.

Cetorelli, N. (2009) Banking and Real Economic Activity. In Berger, A.N., Molyneux, P. and Wilson, J. (eds.) The Oxford Handbook of Banking. Oxford, Oxford University Press.

Cline, W.R. (2015) Too much finance or statistical illusion? Peterson Institute for International Economics, Policy Brief PB 15-9.

Cochrane, J.H. (2015) Economic Growth.

http://faculty.chicagobooth.edu/john.cochrane/research/papers/cochrane_growth.html.

Cojocaru, L., Falaris, E., Hoffman, S. and Miller, J. (2015) Financial System Development and Economic Growth In Transition Economies: New Empirical Evidence From the CEE and CIS Countries. University of Delaware, Working paper, 11-22.

Dal Colle, A. (2011) Finance-growth nexus: does causality withstand financial liberalization? Evidence from cointegrated VAR. Empirical Economics, 41(1), pp. 127-154.

Demetriades, P.O. and Andrianova, S. (2003) Finance and Growth: What We Know and What We Need to Know. In Goodhart, C. (ed.) Financial Development and Economic Growth: Explaining the Links. Hampshire, Palgrave Macmillan.

Demirgüç-Kunt, A. and Maksimovic, V. (1998) Law, Finance, and Firm Growth. Journal of Finance, 53: 2107-2137.

Easterly, W., R. Islam, and J. Stiglitz (2000). Shaken and Stirred: Explaining Growth Volatility, in B. Pleskovic and N. Stern (eds.): Annual Bank Conference on Development Economics. Washington, DC: The World Bank.

Feldstein, M. and Stock, J.H. (1993) The Use of a Monetary Aggregate to Target Nominal $G D P$. NBER Working Paper No. 4304.

Fink, G., Haiss, P. and Vuksic, G. (2009) Contribution of Financial Market Segments at Different Stages of Development: Transition, Cohesion and Mature Economies Compared. Journal of Financial Stability, 5:431-455.

Fischer, S. (1993) The Role of Macroeconomic Factors in Growth. NBER Working Paper, 4565 .

Ghazanchyan, M., Stotsky, J.G and Zhang, Q. (2015) A New Look at the Determinants of Growth in Asian Countries. IMF Working Paper, 195. 
Gimet, C. and Lagoarde-Segot, T. (2012) Financial sector development and access to finance. Does size say it all? Emerging Markets Review, 13(3): 316-337.

Grochowska, A., Diaconescu, I., Margerit, A. and Tomova, R. (2014) Financing the Recovery: the State of Europe's Financial Sector. ECFIN Economic Brief, 33.

Hagmayr, B. and Haiss, P. (2007) Financial Sector Development and Economic Growth Evidence for South-Eastern Europe. In Altzinger, W., Petkova, I. (eds.) Impacts of Foreign Direct Investments on Banking Sectors in South East European Countries. Economic Policy Institute, Sofia.

Haldane, A. (2012) On Being the Right Size. Speech at the Institute of Economic Affairs' 22nd Annual Series, The 2012 Beesley Lectures, at the Institute of Directors, London, October $25,2012$.

Haldane, A. (2015) Growing, Fast and Slow. Speech at the University of East Anglia, February 17, 2015.

Haldane, A., Brennan, S. and Madouros, V. (2010) What is the Contribution of the Financial Sector: Miracle or Mirage? The Future of Finance: The LSE Report, London School of Economics and Political Science.

Holtz-Eakin, D., Newey, W. and Rosen, H.S. (1988). Estimating Vector Autoregressions With Panel Data. Econometrica, 56:1371-1395.

Im, K.S, Pesaran, M.H. and Shin, Y. (2003), Testing for Unit Roots in Heterogeneous Panels, Journal of Econometrics, 115: 53-74.

IMF (2003) Deflation: Determinants, Risks and Policy Options. IMF Occasional Paper, 221.

Kaufmann, D., Kraay, A., and Mastruzzi, M. (2010) The worldwide governance indicators: Methodology and analytical issues. World Bank, Policy Research Working Paper 5430.

King, R.G. and Levine, R. (1993) Finance and Growth: Schumpeter might be right. Quarterly Journal of Economics, 108(3): 717-737.

Kim, D.H., Lin, S.C. \& Yu-Bo Suen, Y.B. (2012) The Simultaneous Evolution of Economic Growth, Financial Development, and Trade Openness. Journal of International Trade and Economic Development: An international and comparative review, 21(4): 513-537.

Levine, R. (2005) Finance and Growth: Theory and Evidence. In Aghion, P. and Durlauf, S.N. (eds.) Handbook of Economic Growth. Amsterdam, Elsevier.

Levine R. (1997). Financial Development and Economic Growth: Views and Agenda. Journal of Economic Literature 35(2): 688-726.

Levine, R., Loayza, N. and Beck, T. (2000) Financial Intermediation and Growth: Causality and Causes. Journal of Monetary Economics 46:31-77.

Levine, R. and Zervos, S. (1998) Stock Markets, Banks, and Economic Growth. American Economic Review 88:537-558.

Levin, Lin and Chu(2002), Unit Root Tests in Panel Data: Asymptotic and Finite-Sample Properties, Journal of Econometrics, 108(1): 1-24. 
Lin, V.L.Y. (1981) The impact of the financial sector on economic development: some crosssection evidence. Studies in Comparative International Development, 16(1): 44-52.

Lucas, R.E., Jr. (1988) On the Mechanics of Economic Development. Journal of Monetary Economics, 22(1): 3-42.

Mankiw, G., Romer, D and Weil, D. (1992) A Contribution to the Empirics of Economic Growth, The Quarterly Journal of Economics, 107(2) (May, 1992): 407-437.

Mumtaz, H., Pinter, G. and Theodoridis, K. (2015) What do VARs Tell us About the Impact of a Credit Supply Shock. University of London, Working Paper, 739.

Odhiambo, N.M. (2007) Financial Depth, Savings and Economic Growth in Kenya: A Dynamic Causal Linkage. Economic Modelling, 25: 704-713.

Oguzoglu, U. and Stengos, T. (2011) Can Dynamic Panel Explain the Finance-Growth Link? An Empirical Likelhood Approach. Review of Economic Analysis, 3: 129-148.

Patrick, H.T. (1966) Financial Development and Economic Growth in Underdeveloped Countries. Economic Development and Cultural Change, 14(2): 174-189.

Rajan, R.G. and Zingales, L. (1998) Financial Dependence and Growth. American Economic Review, 88:559-586.

Rajan, R.G., and Zingales, L. (2003) The Great Reversals: The Politics of Financial Development in the Twentieth Century. Journal of Financial Economics, 69: 5-50.

Robinson, J. (1952) The Generalization of the General Theory. In Robinson, J. (ed.), The Rate of Interest and Other Essays. London, Macmillan.

Roodman, D. (2006). How to Do xtabond2: An Introduction to "Difference" and "System" GMM in Stata. Working Paper, Center for Global Development, London.

Rousseau, P.L. and Wachtel, P. (2002) Inflation Thresholds and the Finance-growth Nexus. Journal of International Money and Finance, 21(6): 777-793.

Rousseau, P.L. and Wachtel, P. (2005) Economic Growth and Financial Depth: Is the Relationship Extinct Already? New York University, Leonard N. Stern School of Business, Department of Economics, Working Papers 05-15.

Rousseau, P.L. and Wachtel, P. (2011) What is Happening to the Impact of Financial Deepening on Economic Growth? Economic Inquiry, 49(1):276-288.

Sakyi, D., Villaverde, J., and Maza, A. (2015) Trade Openness, Income Levels, and Economic Growth: The Case of Developing Countries, 1970-2009. Journal of International Trade and Economic Development: An international and comparative review 24(6): 860-882.

Sala-i-Martin, X. (1997) Transfers, Social Safety Nets, and Growth. IMF Staff Papers, 44(1).

Schnabl, G. (2007) Exchange Rate Volatility and Growth in Emerging Europe and East Asia. CESifo Working Paper No. 2023

Schumpeter, J.A. (1911) A Theory of Economic Development. Cambridge, Harvard University Press. 
Solow, R. (1956) A Contribution to the Theory of Economic Growth. The Quarterly Journal of Economics, 70 (1):65-94.

Stengos, T. and Liang, Z. (2005) Financial Intermediation and Economic Growth: A Semiparametric Approach. Chapter 2:39-52. Berlin, Springer.

Swann, T. (1956) Economic Growth and Capital Accumulation. Economic Record, 32(2): 334-361.

Windmeijer, F. (2005). A finite sample correction for the variance of linear efficient two-step GMM estimators. Journal of Econometrics, 126(1), 25-51.

Winter L. A. (2004) Trade Liberalization and Economic Performance: An Overview. The Economic Journal 114, pp. 4-21.

Yildirim, S., Özdemir, B.K. and Dogan, B. (2013) Financial Development and Economic Growth Nexus in Emerging European Economies: New Evidence From Asymmetric Causality. International Journal of Economics and Financial Issues, 3(3):710-722. 


\section{TABLES:}

Table 1. Growth regressions for all economies in the sample; Dependent variable is GDP per capita growth.

\begin{tabular}{|c|c|c|c|c|c|c|}
\hline \multirow[b]{2}{*}{$\operatorname{gdppc}_{\mathrm{t}-1}$} & \multicolumn{2}{|r|}{ OLS } & \multicolumn{2}{|c|}{ Fixed Effects } & \multicolumn{2}{|c|}{ GMM-SYS } \\
\hline & 0.073 & {$[1.907]^{*}$} & 0.052 & [1.355] & 0.041 & {$[0.367]$} \\
\hline inv & 0.473 & {$[2.786]^{* * *}$} & 0.442 & {$[2.814]^{* * *}$} & 0.501 & [2.818] \\
\hline wage & 0.129 & {$[3.883]^{* * *}$} & 0.13 & {$[3.704] * * *$} & 0.147 & {$[4.034]^{* * *}$} \\
\hline ulc & -0.03 & {$[-2.246]^{* *}$} & -0.026 & {$[-2.150]^{* *}$} & -0.029 & {$[-2.141]^{* *}$} \\
\hline cred & -0.005 & {$[-2.689]^{* * *}$} & -0.008 & {$[-2.185]^{* *}$} & -0.006 & {$[-2.734]^{* * *}$} \\
\hline $\mathrm{ms}$ & 0.045 & {$[3.116]^{* * *}$} & 0.043 & {$[2.939]^{* * *}$} & 0.039 & {$[3.355]^{* * *}$} \\
\hline intm & -0.004 & {$[-0.272]$} & 0.006 & {$[0.463]$} & -0.001 & {$[-0.049]$} \\
\hline gcon & 1.28 & {$[4.422]^{* * *}$} & 1.358 & {$[3.384]^{* * *}$} & 1.291 & {$[3.714]^{* * *}$} \\
\hline open & 0.229 & {$[7.008]^{* * *}$} & 0.237 & {$[6.612]^{* * *}$} & 0.228 & [5.945] \\
\hline $\inf$ & -0.051 & {$[-1.819]^{*}$} & -0.038 & {$[-1.396]$} & -0.059 & {$[-1.680]^{*}$} \\
\hline va & 0.032 & {$[2.227]^{* *}$} & 0.007 & {$[0.258]$} & 0.509 & [1.182] \\
\hline ps & 0.021 & {$[3.903]^{* * *}$} & 0.032 & {$[2.770]^{* * *}$} & 0.556 & {$[2.154]^{* *}$} \\
\hline ge & 0.036 & [1.496] & 0.062 & [1.213] & 0.267 & {$[0.661]$} \\
\hline $\mathrm{rq}$ & 0.028 & [1.247] & -0.021 & {$[-0.833]$} & 0.62 & {$[1.076]$} \\
\hline $\mathrm{rl}$ & 0.067 & {$[2.619]^{* * *}$} & -0.052 & {$[-1.158]$} & 1.197 & {$[2.028]^{* *}$} \\
\hline $\mathrm{cc}$ & 0.024 & {$[3.305]^{* * *}$} & 0.052 & [1.257] & 0.374 & {$[1.896]^{*}$} \\
\hline constant & -0.558 & {$[-1.211]$} & -5.653 & [-1.698] & 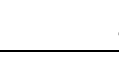 & - \\
\hline $\mathrm{R}^{2}$-Adjusted & & 0.81 & & 82 & & 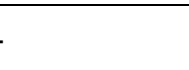 \\
\hline \multicolumn{5}{|c|}{ Number of instruments } & \multicolumn{2}{|c|}{31} \\
\hline \multicolumn{5}{|c|}{$\operatorname{AR}(1)(p \text {-value })^{(1)}$} & \multicolumn{2}{|c|}{0.021} \\
\hline \multicolumn{5}{|c|}{$\operatorname{AR}(2)(p \text {-value })^{(2)}$} & \multicolumn{2}{|c|}{0.106} \\
\hline \multicolumn{5}{|c|}{ Hansen test (p-value) $)^{(3)}$} & \multicolumn{2}{|c|}{0.198} \\
\hline
\end{tabular}

Notes: ${ }^{(1)}$ Test for first order serial correlation; ${ }^{(2)}$ Test for second order serial correlation; ${ }^{(3)}$ Tests the null hypothesis of the appropriate set of instruments. A Hausman test between fixed effects and GMM-SYS indicates that GMM-SYS estimates are consistent $\left(X^{2}\right)=26.57$ and $p$-value $=0.023$ ). Robust (HAC) standard errors have been used in the estimation of both OLS and Fixed Effects models; All the models are based on the two-step estimation procedure and Windmeijer's corrected standard error. Robust $t$ and $z$-statistics are shown in square brackets. Time dummies have been used in the estimation; $(*),(* *)$ and $(* * *)$ denote significance at $10 \%, 5 \%$ and $1 \%$ level respectively. 
Table 2. Growth regressions for the advanced economies in the sample; Dependent variable is GDP per capita growth.

\begin{tabular}{|c|c|c|c|c|c|c|}
\hline \multirow[b]{2}{*}{$\operatorname{gdppc}_{t-1}$} & \multicolumn{2}{|c|}{ OLS } & \multicolumn{2}{|c|}{ Fixed Effects } & \multicolumn{2}{|c|}{ GMM-SYS } \\
\hline & 0.101 & {$[2.042]^{* *}$} & 0.264 & {$[4.646]^{* * *}$} & 0.017 & {$[1.814]^{*}$} \\
\hline inv & 0.743 & {$[11.06]^{* * *}$} & 0.658 & {$[12.52]^{* * *}$} & 0.758 & {$[22.30]^{* * *}$} \\
\hline wage & 0.163 & {$[3.201]^{* * *}$} & 0.146 & {$[2.710]^{* * *}$} & 0.170 & {$[9.012]^{* * *}$} \\
\hline ulc & -0.004 & {$[-0.698]$} & -0.058 & {$[-2.882]^{* *}$} & 0.001 & {$[0.299]$} \\
\hline cred & -0.004 & {$[-3.495] * * *$} & -0.001 & {$[-0.531]$} & -0.005 & {$[-4.834]^{* * *}$} \\
\hline $\mathrm{ms}$ & 0.020 & {$[2.221]^{* *}$} & 0.016 & {$[1.395]$} & 0.019 & {$[3.154]^{* * *}$} \\
\hline intm & -0.042 & {$[-3.437] * * *$} & -0.004 & {$[-0.236]$} & -0.034 & {$[-3.776]^{* * *}$} \\
\hline gcon & 0.754 & {$[3.309]^{* * *}$} & 0.798 & {$[3.145]^{* * *}$} & 0.700 & {$[6.614]^{* * *}$} \\
\hline open & 0.203 & {$[11.01]^{* * *}$} & 0.101 & {$[4.757]^{* * *}$} & 0.202 & {$[24.15]^{* * *}$} \\
\hline inf & -0.061 & {$[-0.672]$} & -0.142 & {$[-1.863]^{*}$} & -0.064 & {$[-2.048]^{* *}$} \\
\hline va & 1.637 & {$[2.320]^{* *}$} & 0.205 & {$[0.265]$} & 1.525 & {$[3.400]^{* * *}$} \\
\hline ps & 0.613 & {$[2.033]^{* *}$} & 1.247 & {$[2.932]^{* * *}$} & 0.867 & {$[4.356]^{* * *}$} \\
\hline ge & 0.156 & {$[0.439]$} & 0.067 & {$[0.131]$} & 0.511 & {$[1.685]^{*}$} \\
\hline $\mathrm{rq}$ & 0.378 & {$[0.937]$} & 0.104 & {$[0.157]$} & 0.442 & [1.592] \\
\hline $\mathrm{rl}$ & -0.939 & {$[-1.421]$} & -0.983 & {$[-1.308]$} & 1.417 & {$[3.737]^{* * *}$} \\
\hline $\mathrm{cc}$ & 0.505 & {$[1.028]$} & 0.518 & {$[0.988]$} & 0.438 & {$[1.648]^{*}$} \\
\hline constant & 1.828 & {$[2.767]^{* * *}$} & 0.158 & {$[0.172]$} & \multicolumn{2}{|c|}{-} \\
\hline $\mathrm{R}^{2}$-Adjusted & \multicolumn{2}{|r|}{0.87} & \multicolumn{2}{|c|}{0.91} & & . \\
\hline \multicolumn{5}{|c|}{ Number of instruments } & \multicolumn{2}{|c|}{$\begin{array}{l}- \\
36\end{array}$} \\
\hline \multicolumn{5}{|c|}{$\mathrm{AR}(1)(\mathrm{p} \text {-value })^{(1)}$} & \multicolumn{2}{|c|}{0.008} \\
\hline \multicolumn{5}{|c|}{$\mathrm{AR}(2)(\mathrm{p} \text {-value })^{(2)}$} & \multicolumn{2}{|c|}{0.399} \\
\hline \multicolumn{5}{|c|}{ Hansen test (p-value) $)^{(3)}$} & \multicolumn{2}{|c|}{0.467} \\
\hline
\end{tabular}

Notes: ${ }^{(1)}$ Test for first order serial correlation; ${ }^{(2)}$ Test for second order serial correlation; ${ }^{(3)}$ Tests the null hypothesis of the appropriate set of instruments. A Hausman test between fixed effects and GMM-SYS indicates that GMM-SYS estimates are consistent $\left(X^{2}\right)=32.77$ and p-value $=0.001$ ). Robust (HAC) standard errors have been used in the estimation of both OLS and Fixed Effects models; All the models are based on the two-step estimation procedure and Windmeijer's corrected standard error. Robust $t$ and $z$-statistics are shown in square brackets. Time dummies have been used in the estimation; $(*),(* *)$ and $(* * *)$ denote significance at $10 \%, 5 \%$ and $1 \%$ level respectively. 
Table 3. Growth regressions for the developing economies in the sample; Dependent variable is GDP per capita growth.

\begin{tabular}{|c|c|c|c|c|c|c|}
\hline \multirow[b]{2}{*}{$\operatorname{gdppc}_{t-1}$} & \multicolumn{2}{|c|}{ OLS } & \multicolumn{2}{|c|}{ Fixed Effects } & \multicolumn{2}{|c|}{ GMM-SYS } \\
\hline & 0.021 & {$[0.5305]$} & 0.017 & {$[0.378]$} & 0.001 & {$[0.033]$} \\
\hline inv & 0.372 & {$[2.036]^{* *}$} & 0.195 & {$[1.603]$} & 0.390 & {$[2.063]^{* *}$} \\
\hline wage & 0.177 & {$[3.668]^{* * *}$} & 0.266 & {$[6.447]^{* * *}$} & 0.214 & {$[3.998]^{* * *}$} \\
\hline ulc & -0.053 & {$[-2.283] * *$} & -0.104 & {$[-4.422]^{* * *}$} & -0.056 & {$[-2.297]^{* *}$} \\
\hline cred & -0.022 & {$[-2.746] * * *$} & -0.065 & {$[-4.004]^{* * *}$} & -0.019 & {$[-1.898]^{*}$} \\
\hline $\mathrm{ms}$ & 0.049 & {$[2.818]^{* * *}$} & 0.033 & {$[2.384]^{* *}$} & 0.043 & {$[3.174]^{* * *}$} \\
\hline intm & 0.047 & {$[1.572]$} & 0.064 & {$[2.769]^{* * *}$} & 0.044 & {$[1.682]^{*}$} \\
\hline gcon & 1.475 & {$[4.295]^{* * *}$} & 1.525 & {$[3.798]^{* * *}$} & 1.626 & {$[3.925]^{* * *}$} \\
\hline open & 0.222 & {$[6.217]^{* * *}$} & 0.185 & {$[3.140]^{* * *}$} & 0.221 & {$[4.899]^{* * *}$} \\
\hline inf & -0.037 & {$[-1.238]$} & 0.023 & {$[0.650]$} & -0.032 & {$[-1.046]$} \\
\hline va & -0.975 & {$[-1.806]^{*}$} & 1.804 & {$[1.799]^{*}$} & -0.847 & {$[-1.414]$} \\
\hline ps & 0.468 & {$[1.844]^{*}$} & 0.887 & {$[2.047]^{* *}$} & 0.544 & {$[1.789]^{*}$} \\
\hline ge & 0.339 & {$[0.364]$} & -0.343 & {$[-0.155]$} & 0.312 & {$[0.301]$} \\
\hline rq & 1.014 & {$[0.867]$} & -1.998 & {$[-1.231]$} & 0.115 & {$[0.088]$} \\
\hline $\mathrm{rl}$ & -0.779 & {$[-0.690]$} & 1.155 & {$[0.492]$} & 0.055 & {$[0.043]$} \\
\hline $\mathrm{cc}$ & 0.853 & {$[3.812]^{* * *}$} & 1.733 & [1.101] & 0.722 & {$[3.110]^{* * *}$} \\
\hline constant & 1.113 & [1.141] & 5.030 & {$[3.960]$} & \multicolumn{2}{|l|}{-} \\
\hline \multicolumn{2}{|l|}{$\mathrm{R}^{2}$-Adjusted } & 0.75 & \multicolumn{2}{|c|}{0.77} & & - \\
\hline \multicolumn{5}{|c|}{ Number of instruments } & \multicolumn{2}{|c|}{40} \\
\hline \multicolumn{5}{|c|}{$\operatorname{AR}(1)(p \text {-value })^{(1)}$} & \multicolumn{2}{|c|}{0.051} \\
\hline \multicolumn{5}{|c|}{$\operatorname{AR}(2)(p \text {-value })^{(2)}$} & \multicolumn{2}{|c|}{0.214} \\
\hline \multicolumn{5}{|c|}{ Hansen test (p-value) $)^{(3)}$} & \multicolumn{2}{|c|}{0.561} \\
\hline \multicolumn{7}{|c|}{$\begin{array}{l}\text { Notes: }{ }^{(1)} \text { Test for first order serial correlation; }{ }^{(2)} \text { Test for second order serial correlation; }{ }^{(3)} \text { Tests the null } \\
\text { hypothesis of the appropriate set of instruments. A Hausman test between fixed effects and GMM-SYS indicates } \\
\left.\text { that GMM-SYS estimates are consistent }\left(X^{2}\right)=45.12 \text { and p-value }=0.000\right) \text {. Robust }(\mathrm{HAC}) \text { standard errors have } \\
\text { been used in the estimation of both OLS and Fixed Effects models; All the models are based on the two-step } \\
\text { estimation procedure and Windmeijer's corrected standard error. Robust t and z-statistics are shown in square } \\
\text { brackets. Time dummies have been used in the estimation; }(*),(* *) \text { and }\left({ }^{* * *}\right) \text { denote significance at } 10 \%, 5 \% \\
\text { and } 1 \% \text { level respectively. }\end{array}$} \\
\hline
\end{tabular}


Table 4. Growth regressions for the eurozone economies in the sample; Dependent variable is GDP per capita growth.

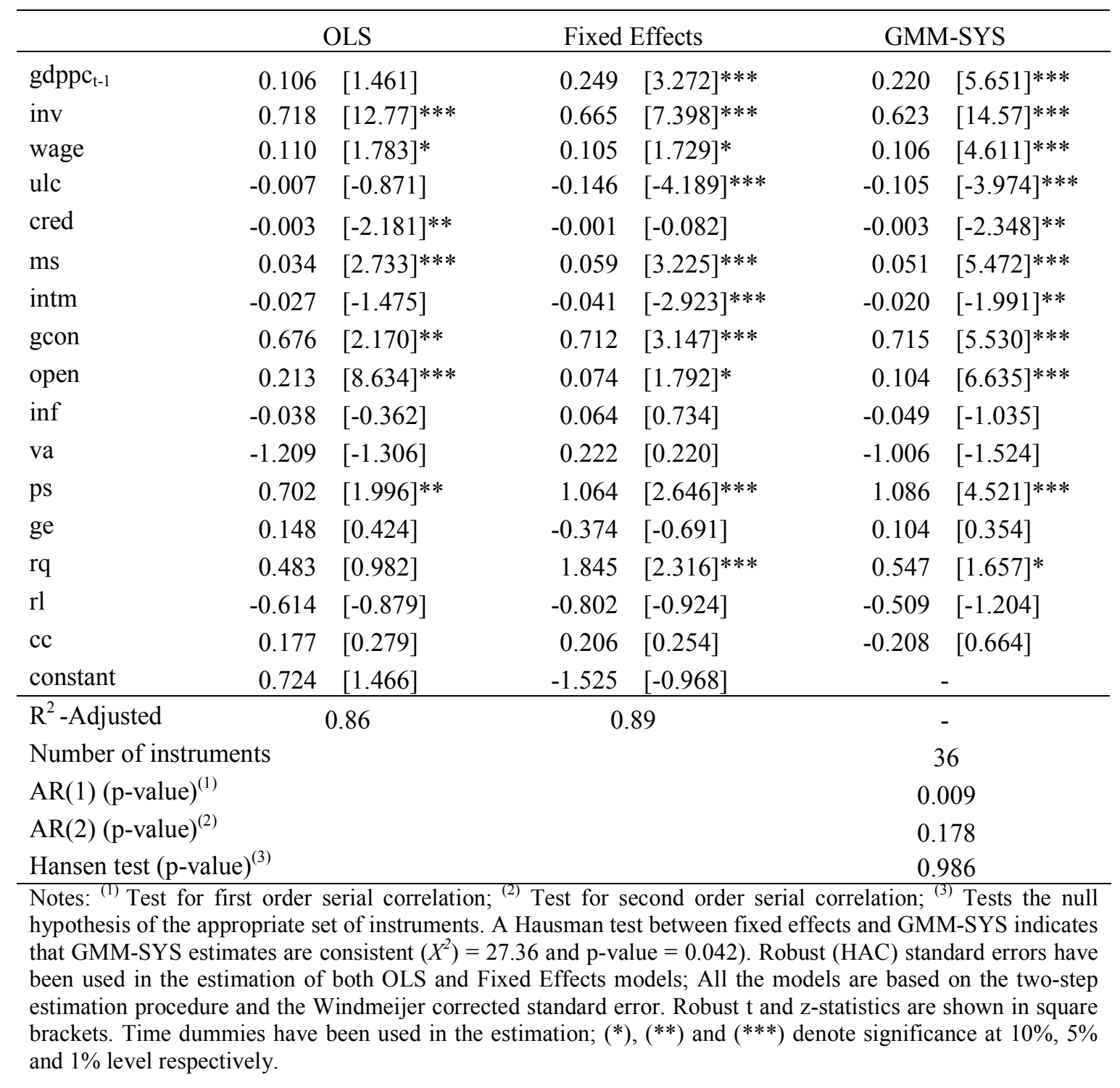




\section{Appendix}

Table A1. The dataset

\begin{tabular}{|c|c|c|}
\hline Name & Variable - Definition & Source \\
\hline RGDPH & Percentage change in real gross domestic product per head. & $\begin{array}{l}\text { Statistical Office of the } \\
\text { European Community. }\end{array}$ \\
\hline INV & Gross fixed investment ( $\%$ real change pa). & $\begin{array}{l}\text { Statistical Office of the } \\
\text { European Community. }\end{array}$ \\
\hline WAGE & $\begin{array}{l}\text { Percentage change in wages, over previous year. Monthly } \\
\text { earnings, wage earners \& salaried employees. }\end{array}$ & OECD. \\
\hline ULC & Unit labour costs ( $\%$ change pa) & OECD. \\
\hline MS & Percentage change in M2 ( $\%$ change pa) & $\begin{array}{l}\text { IMF, International Financial } \\
\text { Statistics. }\end{array}$ \\
\hline CRE & $\begin{array}{l}\text { Domestic credit provided by financial sector (\% of GDP), } \\
\text { excluding credit to the central government. }\end{array}$ & World Bank. \\
\hline INTM & $\begin{array}{l}\text { Interest rate margin; lending interest rate less deposit interest } \\
\text { rate }(\%)\end{array}$ & $\begin{array}{l}\text { IMF, International Financial } \\
\text { Statistics. }\end{array}$ \\
\hline MGDP & Money and quasi money supply (M2) as \% of GDP. & World Bank \\
\hline RINT & Real lending rate $(\%)$ & World Bank \\
\hline STOX & Stocks traded, total value ( $\%$ of GDP). & World Bank \\
\hline MCAP & $\begin{array}{l}\text { Market capitalization of listed domestic companies (\% of } \\
\text { GDP) }\end{array}$ & World Bank \\
\hline DGOV & Government consumption ( $\%$ real change pa) & $\begin{array}{l}\text { IMF, International Financial } \\
\text { Statistics. }\end{array}$ \\
\hline INF & Consumer prices $(\%$ change pa) & $\begin{array}{l}\text { Statistical Office of the } \\
\text { European Community. }\end{array}$ \\
\hline OPEN & Exports of goods and services ( $\%$ real change p.a.) & $\begin{array}{l}\text { Statistical Office of the } \\
\text { European Community. }\end{array}$ \\
\hline VA & $\begin{array}{l}\text { Voice and Accountability (ranges from approximately }-2.5 \\
\text { (weak) to } 2.5 \text { (strong) governance performance). }\end{array}$ & $\begin{array}{l}\text { Worldwide Governance } \\
\text { Indicators. The World Bank } \\
\text { Group. }\end{array}$ \\
\hline PS & $\begin{array}{l}\text { Political Stability and Absence of Violence/Terrorism (ranges } \\
\text { from approximately }-2.5 \text { (weak) to } 2.5 \text { (strong) governance } \\
\text { performance). }\end{array}$ & $\begin{array}{l}\text { Worldwide Governance } \\
\text { Indicators. The World Bank } \\
\text { Group. }\end{array}$ \\
\hline
\end{tabular}


GE Government Effectiveness - (ranges from approximately -2.5 Worldwide Governance (weak) to 2.5 (strong) governance performance). Indicators. The World Bank Group.

RQ Regulatory Quality - (ranges from approximately -2.5 (weak) to 2.5 (strong) governance performance).

Worldwide Governance Indicators. The World Bank Group.

RL Rule of Law - (ranges from approximately -2.5 (weak) to 2.5 Worldwide Governance (strong) governance performance). Indicators. The World Bank Group.

CC Control of Corruption - (ranges from approximately -2.5 (weak) to 2.5 (strong) governance performance).

Worldwide Governance Indicators. The World Bank Group. 
Table A2. Descriptive statistics

\begin{tabular}{lccccc}
\hline Variables & Mean & Median & Min & Max & Std. Dev. \\
\hline$D G O V$ & 2.325 & 1.929 & -15.291 & 44.532 & 4.858 \\
$W A G E$ & 2.828 & 1.631 & -23.206 & 30.100 & 5.305 \\
$M S$ & 13.095 & 8.202 & -28.527 & 160.808 & 18.240 \\
$I N F$ & 5.271 & 2.582 & -8.592 & 94.860 & 9.816 \\
$U L C$ & 4.671 & 3.706 & -47.769 & 109.506 & 11.904 \\
$R G D P H$ & 2.599 & 2.366 & -14.565 & 33.200 & 4.581 \\
$I N V$ & 0.687 & 0.655 & -15.468 & 26.313 & 2.824 \\
$C R E$ & 93.678 & 83.300 & 8.696 & 347.338 & 60.843 \\
$I N T M$ & 2.657 & 2.418 & -73.239 & 57.978 & 9.646 \\
$O P E N$ & 5.630 & 5.172 & -43.335 & 48.943 & 8.836 \\
$V A$ & 1.191 & 1.167 & 0.564 & 1.626 & 0.249 \\
$P S$ & 0.782 & 0.811 & -0.223 & 1.425 & 0.370 \\
$G E$ & 1.277 & 1.375 & 0.307 & 2.258 & 0.488 \\
$R Q$ & 1.226 & 1.262 & 0.344 & 1.903 & 0.411 \\
$R L$ & 1.257 & 1.360 & 0.337 & 2.120 & 0.526 \\
$C C$ & 1.145 & 1.271 & -0.254 & 2.303 & 0.724 \\
\hline
\end{tabular}


Table A3. Countries used in the analysis and their classification

\begin{tabular}{|l|l|}
\hline Advanced economies & Developing market economies \\
\hline Austria & Azerbaijan \\
Belgium & Bulgaria \\
Cyprus & Croatia \\
Czech Republic & Hungary \\
Denmark & Kazakhstan \\
Estonia & Lithuania \\
Finland & Poland \\
France & Romania \\
Germany & Russia \\
Greece & Serbia \\
Ireland & Turkey \\
Italy & Ukraine \\
Latvia & \\
Netherlands & \\
Norway & \\
Portugal & \\
Slovakia & \\
Slovenia & \\
Spain & \\
Sweden & \\
Switzerland & \\
United Kingdom & \\
Notes: & \\
\hline
\end{tabular}

Notes: (1) The classification in advanced and developing countries follows the World Economic Outlook Database, October 2014. (2) Eurozone counties: Austria, Belgium, Cyprus, Estonia, Finland, France, Germany, Greece, Ireland, Italy, Latvia, Luxembourg, Malta, the Netherlands, Portugal, Slovakia, Slovenia and Spain. The present paper does not include Malta and Estonia due to missing data. Latvia, which adopted euro on January 1, 2014 is not included in the eurozone countries in the empirical analysis. 
Table A4. Panel Unit root tests

\begin{tabular}{lrlrlrl}
\hline & \multicolumn{2}{c}{ LLC } & \multicolumn{2}{c}{ IPS } & \multicolumn{2}{c}{ ADF-Fisher } \\
\hline gdppc & -8.184 & {$[0.000]$} & -5.103 & {$[0.000]$} & 134.91 & {$[0.000]$} \\
inv & -7.662 & {$[0.000]$} & -3.893 & {$[0.000]$} & 124.08 & {$[0.000]$} \\
wage & -6.977 & {$[0.000]$} & -5.967 & {$[0.000]$} & 175.30 & {$[0.000]$} \\
ulc & -10.703 & {$[0.000]$} & -7.641 & {$[0.000]$} & 176.69 & {$[0.000]$} \\
cred & -4.448 & {$[0.000]$} & -5.898 & {$[0.000]$} & 156.01 & {$[0.000]$} \\
ms & -4.090 & {$[0.000]$} & -2.502 & {$[0.006]$} & 90.990 & {$[0.032]$} \\
intm & -4.672 & {$[0.000]$} & -3.982 & {$[0.000]$} & 120.76 & {$[0.000]$} \\
gcon & -5.610 & {$[0.000]$} & -5.729 & {$[0.000]$} & 150.81 & {$[0.000]$} \\
open & -12.083 & {$[0.000]$} & -4.090 & {$[0.000]$} & 90.99 & {$[0.032]$} \\
inf & -15.587 & {$[0.000]$} & -7.506 & {$[0.000]$} & 176.50 & {$[0.000]$} \\
\hline
\end{tabular}

Note: In all cases the null hypothesis of a unit root is rejected at the $5 \%$ level of significance. 
Table A5. GMM-SYS Growth regression estimates for all different clusters (1998-2008); Dependent variable: GDP per capita growth.

\begin{tabular}{|c|c|c|c|c|c|c|c|c|}
\hline \multirow{3}{*}{$\begin{array}{l}\text { gdppc }_{t-1} \\
\text { inv }\end{array}$} & \multicolumn{2}{|c|}{ All Economies } & \multicolumn{2}{|c|}{ Advanced Economies } & \multicolumn{2}{|c|}{ Eurozone Countries } & \multicolumn{2}{|c|}{ Developing Economies } \\
\hline & 0.006 & [1.430] & 0.165 & {$[3.747]^{* * *}$} & 0.219 & {$[2.621]^{* * *}$} & -0.149 & {$[-1.621]$} \\
\hline & 0.188 & {$[5.145]^{* * *}$} & 0.527 & {$[11.90]^{* * *}$} & 0.540 & {$[9.579]^{* * *}$} & 0.124 & {$[2.049]^{* *}$} \\
\hline wage & 0.209 & {$[8.590]^{* * *}$} & 0.254 & {$[9.836]^{* * *}$} & 0.189 & {$[5.853]^{* * *}$} & 0.200 & {$[4.941]^{* * *}$} \\
\hline ulc & -0.065 & {$[-8.590]^{* * *}$} & -0.021 & {$[-3.701] * * *$} & -0.026 & {$[-3.819]^{* * *}$} & -0.075 & {$[-4.203]^{* * *}$} \\
\hline cred & -0.011 & {$[-4.467]^{* * *}$} & -0.004 & {$[-2.643]^{* * *}$} & -0.004 & {$[-2.052]^{* *}$} & -0.042 & {$[-2.362]^{* *}$} \\
\hline $\mathrm{ms}$ & 0.031 & {$[5.475]^{* * *}$} & 0.004 & {$[0.594]$} & 0.024 & {$[2.505]^{* *}$} & 0.039 & {$[4.370]^{* * *}$} \\
\hline intm & 0.010 & {$[1.121]$} & -0.015 & {$[-1.699]^{*}$} & -0.017 & {$[-1.625]$} & 0.041 & {$[2.064]^{* *}$} \\
\hline gcon & 1.417 & {$[10.65]^{* * *}$} & 0.514 & {$[4.162]^{* * *}$} & 0.320 & {$[2.228]^{* *}$} & 1.800 & {$[7.714]^{* * *}$} \\
\hline open & 0.160 & {$[11.30]^{* * *}$} & 0.150 & {$[13.80]^{* * *}$} & 0.155 & {$[11.62]^{* * *}$} & 0.184 & {$[7.074] * * *$} \\
\hline $\inf$ & -0.049 & {$[-3.842]^{* * *}$} & -0.246 & {$[-6.352]^{* * *}$} & -0.165 & {$[-3.201]^{* * *}$} & -0.050 & {$[-2.040]^{* *}$} \\
\hline va & -0.973 & {$[-0.836]$} & -0.852 & {$[-1.527]$} & 1.414 & {$[2.284]^{* *}$} & -0.629 & {$[-0.922]$} \\
\hline ps & 0.427 & {$[1.653]^{*}$} & 0.891 & {$[4.101]^{* * *}$} & 1.020 & {$[3.669]^{* * *}$} & 0.087 & {$[0.190]$} \\
\hline ge & 0.455 & [0.980] & 0.485 & {$[1.460]$} & 0.351 & {$[1.047]$} & 0.503 & {$[0.384]$} \\
\hline rq & 0.969 & {$[2.182]^{* *}$} & 0.369 & {$[1.063]$} & 0.834 & {$[1.947]^{*}$} & -0.243 & {$[-0.227]$} \\
\hline $\mathrm{rl}$ & 1.474 & {$[2.692]^{* * *}$} & -0.856 & {$[-1.586]$} & -0.411 & {$[-0.816]$} & -0.231 & {$[-0.172]$} \\
\hline $\mathrm{cc}$ & 0.075 & {$[0.471]$} & 0.460 & {$[1.460]$} & -0.584 & {$[-1.498]$} & 0.522 & {$[1.772]^{*}$} \\
\hline \multicolumn{2}{|c|}{ No. of Instruments } & 32 & & 40 & & 41 & & 42 \\
\hline \multicolumn{2}{|c|}{$\operatorname{AR}(1)(p-v a l u e)^{(1)}$} & 0.002 & & 0.046 & & 0.051 & & 0.048 \\
\hline \multicolumn{2}{|c|}{$\operatorname{AR}(2)(p-v a l u e)^{(2)}$} & 0.456 & & 0.731 & & 0.199 & & 0.223 \\
\hline \multicolumn{2}{|c|}{ Hansen (p-value) $)^{(3)}$} & 0.336 & & 0.098 & & 0.125 & & 0.169 \\
\hline
\end{tabular}

Notes: ${ }^{(1)}$ Test for first order serial correlation; ${ }^{(2)}$ Test for second order serial correlation; ${ }^{(3)}$ Tests the null hypothesis of the appropriate set of instruments; All the models are based on the two-step estimation procedure and Windmeijer's corrected standard error. Robust $\mathrm{z}$ statistics are shown in square brackets. Time dummies have been used in the estimation; $(*),(* *)$ and $(* * *)$ denote significance at $10 \%$, $5 \%$ and $1 \%$ level respectively. 
Table A6. Growth regressions for all country groups for the period 2009-2014; Dependent variable: GDP per capita growth.

\begin{tabular}{|c|c|c|c|c|c|c|c|c|}
\hline \multirow{3}{*}{$\begin{array}{l}\operatorname{gdppc}_{\mathrm{t}-1} \\
\text { inv }\end{array}$} & \multicolumn{2}{|c|}{ All Economies } & \multicolumn{2}{|c|}{ Advanced Economies } & \multicolumn{2}{|c|}{ Eurozone Countries } & \multicolumn{2}{|c|}{ Developing Economies } \\
\hline & 0.216 & {$[2.428]^{* *}$} & -0.006 & {$[-0.149]$} & 0.060 & {$[0.876]$} & 0.058 & {$[0.570]$} \\
\hline & 0.524 & {$[8.004]^{* * *}$} & 0.599 & {$[7.934] * * *$} & 0.379 & {$[3.093]^{* * *}$} & 0.271 & {$[1.761]^{*}$} \\
\hline wage & 0.237 & {$[2.648]^{* * *}$} & 0.112 & {$[1.901]^{*}$} & 0.030 & {$[0.433]$} & 0.471 & {$[3.627]^{* * *}$} \\
\hline ulc & -0.142 & {$[-4.185]^{* * *}$} & 0.021 & {$[1.534]$} & 0.037 & {$[2.444]^{* *}$} & -0.100 & {$[-2.096]^{* *}$} \\
\hline cred & -0.007 & {$[-2.904] * * *$} & -0.003 & {$[-2.202]^{* *}$} & -0.004 & {$[-2.073]^{* *}$} & -0.066 & {$[-2.268]^{* *}$} \\
\hline gcon & 0.391 & {$[1.561]$} & 0.869 & {$[3.313]^{* * *}$} & 0.666 & {$[1.855]^{*}$} & -0.761 & {$[1.545]$} \\
\hline open & 0.117 & {$[3.949]^{* * *}$} & 0.236 & {$[10.63]^{* * *}$} & 0.339 & {$[9.656]^{* * *}$} & 0.067 & [1.542] \\
\hline inf & 0.112 & {$[1.578]$} & 0.174 & {$[1.834]^{*}$} & 0.108 & {$[0.709]^{* * *}$} & 0.147 & [1.548] \\
\hline va & -0.142 & {$[-0.277]$} & -0.342 & {$[-1.228]$} & 1.345 & {$[1.284]$} & 0.299 & {$[0.601]$} \\
\hline ps & -0.184 & {$[-0.528]^{*}$} & 1.169 & {$[2.458] * * *$} & 2.237 & {$[3.689] * * *$} & 0.187 & {$[0.290]$} \\
\hline $\mathrm{cc}$ & 0.615 & {$[2.168]^{* *}$} & 2.938 & {$[5.542]^{* * *}$} & 2.228 & {$[3.084]^{* * *}$} & 0.656 & {$[0.719]$} \\
\hline \multicolumn{2}{|c|}{ No. of Instruments } & 38 & \multicolumn{2}{|c|}{37} & \multicolumn{2}{|c|}{40} & \multicolumn{2}{|c|}{39} \\
\hline \multirow{2}{*}{\multicolumn{2}{|c|}{$\operatorname{AR}(1)(p-v a l u e)^{(1)}$}} & 0.052 & \multicolumn{2}{|c|}{0.013} & \multicolumn{2}{|c|}{0.009} & \multicolumn{2}{|c|}{0.002} \\
\hline & & 0.278 & \multicolumn{2}{|c|}{0.929} & \multicolumn{2}{|c|}{0.091} & \multicolumn{2}{|c|}{0.792} \\
\hline Hansen ( & & 0.122 & \multicolumn{2}{|c|}{0.101} & \multicolumn{2}{|c|}{0.272} & \multicolumn{2}{|c|}{0.678} \\
\hline
\end{tabular}

Notes: ${ }^{(1)}$ Test for first order serial correlation; ${ }^{(2)}$ Test for second order serial correlation; ${ }^{(3)}$ Tests the null hypothesis of the appropriate set of instruments; All the models are based on the two-step estimation procedure and Windmeijer's corrected standard error. Robust zstatistics are shown in square brackets. Time dummies have been used in the estimation; $(*),(* *)$ and $(* * *)$ denote significance at $10 \%$, $5 \%$ and $1 \%$ level respectively. 
Figure 1. Domestic credit to GDP (\%)

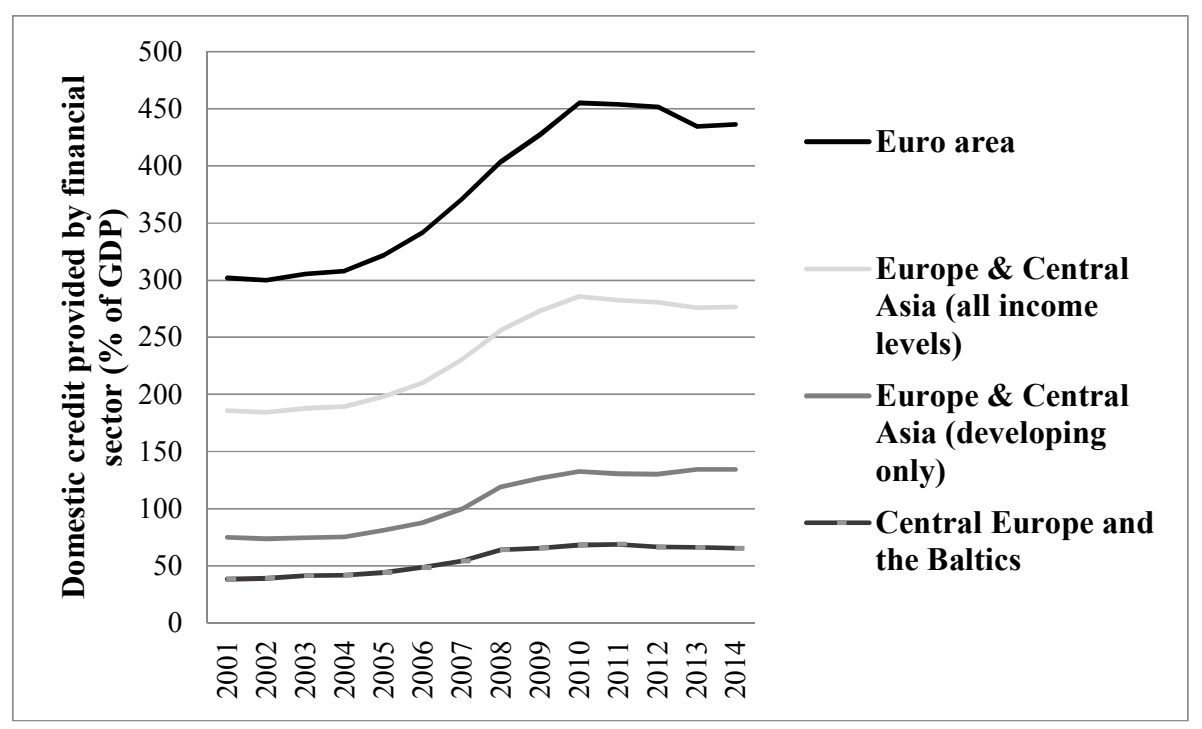

Source: World Bank. 